\title{
PERBANDINGAN ANALISIS BIPLOT KLASIK DAN ROBUST BIPLOT PADA PEMETAAN PERGURUAN TINGGI SWASTA DI JAWA TIMUR
}

\author{
W. Widowati ${ }^{1}$, L. Muzdalifah ${ }^{2}$ \\ ${ }^{1}$ Fakultas MIPA Universitas PGRI Ronggolawe (UNIROW) Tuban, whindhaw87@gmail.com \\ ${ }^{2}$ Fakultas MIPA Universitas PGRI Ronggolawe (UNIROW) Tuban, moezdalif_ah@yahoo.co.id
}

\begin{abstract}
ABSTRAK
Perguruan tinggi di Indonesia kini sudah tersebar diseluruh penjuru tanah air. Perguruan tinggi dapat berbentuk akademi, institut, politeknik, sekolah tinggi, universitas dan akademi komunitas. Untuk melihat adanya kemiripan 331 PTS di Jawa Timur berdasarkan bentuk perguruan tinggi penulis membandingkan analisis biplot klasik dan robust biplot. Analisis biplot merupakan salah satu analisis multivariant yang menyajikan secara visual pemetaan antara segugus objek pengamatan dan peubah dalam suatu grafik dua dimensi [1]. Dasar dari analisis Biplot adalah Singular Value Decomposition (SVD) yang memerlukan matriks data. Pada penelitian ini akan dipetakan segugus obyek berupa Perguruan Tinggi Swasta (PTS) di Jawa Timur berdasarkan bentuk perguruan tinggi dengan peubah berupa jumlah program studi, jumlah dosen tetap, jumlah mahasiswa, akreditasi PTS,jumlah jenjang pendidikan, rasio dosen terhadap mahasiswa, dan biaya pendidikan. Dari hasil analisis biplot klasik dan Robust biplot diperoleh beberapa informasi, yaitu terbentuknya beberapa kelompok PTS, keragaman peubah, korelasi antar peubah dan nilai peubah pada suatu objek. Nilai kesesuaian antara biplot klasik dan robust biplot hampir sama, keduanya memiliki nilai mendekati satu maka biplot yang dihasilkan sangat baik. Namun pada pemetaan PTS di Jawa Timur analisis menggunakan biplot klasik menunjukkan hasil yang lebih baik dari robust biplot.
\end{abstract}

Kata kunci : Biplot Klasik, Robust Biplot, SVD, PTS

\section{Pendahuluan}

Perguruan tinggi di Indonesia kini sudah tersebar diseluruh penjuru tanah air. Perguruan tinggi dapat berbentuk akademi, institut, politeknik, sekolah tinggi, dan universitas. Perguruan tinggi dapat menyelenggarakan pendidikan akademik, profesi dan vokasi dengan program pendidikan Diploma (D1, D2, D3, D4), Sarjana (S1), Magister (S2), Doktor (S3), dan Spesialis. Saat ini jumlah perguruan tinggi di Indonesia sudah 4.430 yang terdiri dari 370 Perguruan Tinggi Negeri (PTN) dan 4.060 Perguruan Tinggi Swasta (PTS) dengan jumlah program studi 23.869 (forlap.dikti.go.id, 2016).

Pemetaan perguruan tinggi pada suatu wilayah tertentu dapat digunakan untuk mengetahui segmentasi pasar, target pasar dan posisi perguruan tinggi tersebut terhadap pesaingnya. Sehingga segmen pasar yang akan dibidik jadi lebih jelas dan terarah. Penelitian ini fokus menganalisis pemetaan PTS di Jawa Timur berdasarkan data dari kopertis wilayah VII. Tujuan dari penelitian ini adalah untuk melihat adanya kemiripan atau tingkat persaingan 331 PTS di Jawa Timur berdasarkan bentuk perguruan tinggi. Metode yang digunakan untuk melakukan pemetaan adalah analisis biplot klasik dan robust biplot. Penelitian ini akan membandingkan hasil analisis biplot klasik dan robust biplot untuk melihat pemetaan PTS di Jawa Timur. 
Penelitian yang dilakukan oleh Gunarto [2] hanya menggunakan analisis biplot dengan variabel-variabel yang diamati adalah atribut yang ada dalam laporan PDPT, yaitu: 1) Luas Sarana Prasarana, 2) Jumlah Judul Buku, 3) Jumlah Tenaga Administrasi, 4) JumlahProgram Studi,5) Jumlah Dosen Tetap,6) Jumlah Mahasiswa,dan 7) Rasio Dosen terhadap Mahasiswa. Analisis biplot yang dilakukan dibantu dengan software SPSS for Windows. Dari penelitian tersebut, peneliti ingin mengembangkan analisis biplot yang ada dengan membandingkan analisis biplot klasik dan robust biplot pada pemetaan PTS yang ada di Jawa Timur. Variabel yang akan digunakan antara lain 1) Jumlah Program Studi, 2) Jumlah Dosen Tetap, 3) Jumlah Mahasiswa, 4) Akreditasi PTS, 5) Jumlah Jenjang Pendidikan, 6) Rasio Dosen terhadap Mahasiswa dan 7) Biaya Pendidikan. Pada analisis ini akan dibantu dengan software SCILAB dan MATLAB.

Analisis biplot pertama kali diperkenalkan oleh Gabriel [3]. Analisis ini didasarkan pada Singular Value Decomposition (SVD). Biplot dapat dibangun dari suatu matriks data, dengan masing-masing kolom mewakili variabel, dan masing-masing baris mewakili objek penelitian. Beberapa informasi penting yang bisa didapatkan dari tampilan biplot antara lain :

1) Kedekatan antar objek, dua objek yang memiliki karakteristik sama akan digambarkan sebagai dua titik dengan posisi yang berdekatan

2) Keragaman variabel, variabel yang mempunyai nilai keragaman yang kecil digambarkan sebagai vektor pendek sedangkan variabel dengan nilai keragaman yang besar digambarkan sebagai vektor panjang

3) Korelasi antar variabel, dua variabel yang memiliki nilai korelasi positif akan digambarkan sebagai dua buah garis dengan arah yang sama atau membentuk sudut sempit (lancip). Sementara itu,dua variabel yang memiliki nilai korelasi negatif akan digambarkan dalam bentuk dua garis dengan arah yang berlawanan atau membentuk sudut lebar (tumpul). Sedangkan dua variabel yang tidak berkolerasi akan digambarkan dalam bentuk dua garis dengan sudut yang mendekati $90^{\circ}$ (siku-siku).

4) Nilai variabel pada suatu objek, informasi ini digunakan untuk melihat keunggulan dari setiap objek.

\subsection{Analisis Biplot Klasik}

Analisis ini didasarkan pada Singular Value Decomposition (SVD). Biplot dapat dibangun dari suatu matriks data, dengan masing-masing kolom mewakili suatu variabel, dan masingmasing baris mewakili objek penelitian.

$$
X=\left[\begin{array}{cccc}
X_{11} & X_{12} & \ldots & X_{1 p} \\
X_{21} & X_{22} & \ldots & X_{2 p} \\
\vdots & \vdots & \ddots & \vdots \\
X_{n 1} & X_{n 2} & \ldots & X_{n p}
\end{array}\right]
$$

Matriks $X$ adalah matriks yang memuat variabel-variabel yang akan diteliti sebanyak $p$ dan objek penelitian sebanyak $n$. Pendekatan langsung digunakan untuk mendapatkan nilai singularnya, yaitu dengan persamaan matriks $X$ berukuran $n \times p$ yang berisi $n$ objek dan $p$ variabel yang dikoreksi terhadap rata-ratanya dan mempunyai rank $r$, dituliskan sebagai berikut

dengan $r \leq\{n, p\}$.

$$
{ }_{n} X_{p}={ }_{n} U_{r r} L_{r} A_{p}^{\prime}
$$

Matriks $\boldsymbol{U}$ dan $\boldsymbol{A}$ adalah matriks kolom ortonormal, dengan $\boldsymbol{U}^{\prime} \boldsymbol{U}=\boldsymbol{A}^{\prime} \boldsymbol{A}=\boldsymbol{I}_{\boldsymbol{r}}$ (matriks identitas berdimensi $r$ ). $\boldsymbol{L}$ adalah matriks diagonal berukuran $(r x r)$ dengan unsur-unsur diagonalnya adalah akar dari nilai eigen-nilai eigen $\mathbf{X}^{\prime} \mathbf{X}$, yaitu $\sqrt{\lambda_{1}} \geq \sqrt{\lambda_{2}} \geq \cdots \geq \sqrt{\lambda_{r}}$.

Unsur-unsur diagonal matriks $\boldsymbol{L}$ ini disebut nilai singular matriks $\mathbf{X}$ dan kolom-kolom matriks $\mathbf{A}$ adalah vektor eigen dari $\mathbf{X}^{\prime} \mathbf{X}$. Kolom-kolom untuk matriks $\boldsymbol{U}$ diperoleh dari $\boldsymbol{u}_{i}=$ 
$\frac{1}{\sqrt{\lambda_{1}}} \boldsymbol{X} \boldsymbol{a}_{\boldsymbol{i}}, i=1,2, \ldots r$ dengan $\boldsymbol{u}_{i}$ adalah vektor yang merupakan kolom ke-i dari matriks $\boldsymbol{U}, \boldsymbol{a}_{\boldsymbol{i}}$ adalah vektor yang merupakan kolom ke-i dari matriks $\mathbf{A}$ dan $\lambda_{i}$ adalah nilai eigen ke-i. Kemudian didefinisikan $\mathbf{L}^{\propto}$ dengan $0 \leq \propto \leq 1$ adalah matriks diagonal berukuran $r x r$ dengan unsur-unsur diagonalnya $\sqrt{\lambda_{1}^{\alpha}} \geq \sqrt{\lambda_{2}^{\alpha}} \geq \cdots \geq \sqrt{\lambda_{r}^{\alpha}}$ dan definisi ini berlaku pula untuk $\mathbf{L}^{1-\alpha}$ dengan unsur-unsur diagonalnya adalah $\sqrt{\lambda_{1}^{1-\alpha}} \geq \sqrt{\lambda_{2}^{1-\alpha}} \geq \cdots \geq \sqrt{\lambda_{r}^{1-\alpha}}$, [4].

Menurut Jollife [1], misalkan $\boldsymbol{G}=\boldsymbol{U} \boldsymbol{L}^{\boldsymbol{\alpha}}$ dan $\boldsymbol{H}^{\prime}=\boldsymbol{L}^{\mathbf{1 - \alpha}} \boldsymbol{A}^{\prime}$ dengan $\alpha$ besarnya $0 \leq \alpha \leq 1$. Persamaan (1) menjadi,

$$
\begin{aligned}
\boldsymbol{X} & =\boldsymbol{U} L^{\alpha} L^{1-\alpha} A^{\prime} \\
& =G H^{\prime}
\end{aligned}
$$

Hal ini berarti unsur ke- $(i, j)$ matriks $X$ dapat dituliskan sebagai

$$
x_{i j}=g_{i}^{\prime} h_{j}
$$

dengan $i=1,2, \ldots$ n dan $j=1,2, \ldots$ p serta $\mathbf{g}_{\mathbf{i}}^{\prime}$ dan $\mathbf{h}_{\mathbf{j}}$ masing-masing merupakan baris matriks $\mathbf{G}$ dan kolom matriks $\mathbf{H} . \mathbf{g}_{\mathbf{i}}^{\prime}$ dan $\mathbf{h}_{\mathbf{j}}$ mempunyai $r$ dimensi. Jika $\mathbf{X}$ mempunyai rank dua, vektor baris $\mathbf{g}_{\mathbf{i}}^{\prime}$ dan vektor $\mathbf{h}_{\mathbf{j}}$ dapat digambarkan dalam ruang berdimensi dua. Jika $\mathbf{X}$ mempunyai rank lebih dari dua maka

$$
x_{i j}=\sum_{k=1}^{r} u_{i k} \lambda_{k}^{\frac{1}{2}} a_{j k}
$$

dengan $u_{i k}$ adalah elemen ke-(i,k) dari matriks $\mathbf{U}, a_{j k}$ adalah elemen ke-(j,k) dari matriks $\mathbf{A}$ dan $\lambda_{k}^{\frac{1}{2}}$ adalah elemen diagonal ke-k dari matriks L. Jika ada sebanyak $m$ elemen unsur yang dipertahankan, persamaan (2) dapat didekati dengan

$$
\begin{aligned}
{ }_{m} \bar{x}_{i j} & =\sum_{k=1}^{m} u_{i k} \lambda_{k}^{\frac{1}{2}} a_{j k}, m<r \\
{ }_{m} \bar{x}_{i j} & =\sum_{k=1}^{m} u_{i k}\left(\lambda_{k}^{\alpha}\right)^{\frac{1}{2}}\left(\lambda_{k}^{1-\alpha}\right)^{\frac{1}{2}} a_{j k} \\
& =\sum_{k=1}^{m} g_{i k}^{\prime} h_{j k} \\
& =g_{i}^{*} h_{j}^{*}
\end{aligned}
$$

dengan $g_{i}^{*}$ dan $h_{j}^{*}$ masing-masing berisi elemen unsur vektor $\mathbf{g}_{\mathbf{i}}$ dan $\mathbf{h}_{\mathbf{j}}$. Gabriel [3] menyatakan bahwa jika $m=2$ maka disebut biplot, sehingga persamaan (3) dapat dinyatakan sebagai :

$$
{ }_{2} x_{i j}=g_{i}^{*} h_{j}^{*}
$$

Dengan ${ }_{2} x_{i j}$ merupakan unsur pendekatan matriks $\mathbf{X}$ pada dimensi dua, sedangkan $g_{i}^{*}$ dan $h_{j}^{*}$ masing-masing mengandung dua unsur pertama vektor $\mathbf{g}_{\mathbf{i}}$ dan $\mathbf{h}_{\mathbf{j}}$.

Dari pendekatan matriks $\mathbf{X}$ pada dimensi dua diperoleh matriks $\mathbf{G}$ dan $\mathbf{H}$ sebagai berikut

$$
G=\left[\begin{array}{cc}
g_{11} & g_{12} \\
\vdots & \vdots \\
g_{i 2} & g_{i 2} \\
\vdots & \vdots \\
g_{n 1} & g_{n 2}
\end{array}\right] \text { dan } H=\left[\begin{array}{cc}
h_{11} & h_{12} \\
\vdots & \vdots \\
h_{i 2} & h_{i 2} \\
\vdots & \vdots \\
h_{p 1} & h_{p 2}
\end{array}\right]
$$

Matriks $\mathrm{G}$ adalah titik-titik koordinat dari $n$ objek dan matriks $\mathbf{H}$ adalah titik-titik koordinat dari $p$ variabel. Langkah-langkah dalam analisis biplot klasik yaitu :

1. Menyiapkan data yang akan digunakan dalam penelitian (data berukuran $n x p$ )

2. Menyusun matriks data $X$

3. Membuat matriks L, A, dan matriks U dengan metode Singular Value Decomposition (SVD) 
4. Membuat matriks $\mathrm{G}=\mathrm{UL}^{\alpha}$ serta $\mathrm{H}^{\prime}=\mathrm{L}^{1-\alpha} \mathrm{A}^{\prime}$

5. Mengambil 2 kolom pertama dari masing-masing matriks $\mathbf{G}$ dan $\mathbf{H}$ sehingga menjadi matriks $\mathbf{G} 2$ dan $\mathbf{H} \mathbf{2}$

6. Membuat grafik koordinat $\mathbf{Z}$ dari masing-masing matriks $\mathbf{G}$ dan $\mathbf{H}$, dimana setiap matriks G2 merupakan koordinat (x,y) untuk masing-masing objek, sedangkan setiap baris dari matriks $\mathbf{H} \mathbf{2}$ merupakan koordinat $(\mathrm{x}, \mathrm{y})$ untuk setiap variabel.

\subsection{Analisis Robust Biplot}

Pada analisis robust biplot, analisis biplot dapat dibangkitkan dengan menggunakan matriks covariance yang robust. Analisis tersebut dilakukan dengan menduga eigen value, eigen vector kiri $(\boldsymbol{U})$, dan eigen vector kanan $(\boldsymbol{A})$ sehingga hasil dugaan tersebut tahan terhadap data outlier [5]. Langkah-langkah dalam analisis biplot RSVD adalah sebagai berikut :

1. Membentuk matriks data observasi ${ }_{n} \boldsymbol{X}_{\boldsymbol{p}}$

2. Melakukan transformasi terhadap median sehingga diperoleh matriks $X^{*}$ menggunakan persamaan $X_{n x p}{ }^{*}=X_{n x p}-\left({ }_{n} j_{1}\right.$ median $\left.\mathrm{X}\right)$

3. Menggunakan algoritma L1 Robust $S V D$ untuk mencari vektor ciri kiri $\left(\mathbf{u}_{1}, \mathbf{u}_{2}, \ldots, \mathbf{u}_{\mathbf{r}}\right)$, vektor ciri kanan $\left(\mathbf{a}_{1}, \mathbf{a} 2, \ldots, \mathbf{a}_{\mathbf{r}}\right)$ dan akar ciri $\left(\left(\lambda_{1}, \lambda_{2}, \ldots \lambda_{r}\right),(r \leq \min \{n, p\})\right.$ sehingga terbentuk matriks $\mathbf{U}, \mathbf{L}$ dan A. Berikut ini adalah algoritma RSVD :

a. Menentukan penduga awal vektor eigen kiri $\boldsymbol{u}_{\mathbf{1}}$

b. Untuk setiap kolom $j, j=1,2, \ldots, \mathrm{p}, c_{j}$ sebagai koefisien regresi $\boldsymbol{L}_{1}$ dengan meminimumkan $\sum_{i=1}^{n}\left(x_{i j}-c_{j} u_{i 1}\right)$

c. Menghitung hasil pendugaan vektor ciri kanan yaitu $a_{1}=\frac{c}{\|c\|}$

d. Menggunakan hasil pendugaan vektor ciri kanan untuk memperhalus pendugaan vektor ciri kiri. Untuk setiap baris $i, i=1,2, \ldots$, n dengan menentukan $d_{i}$ sebagai koefisien regresi $\boldsymbol{L}_{1}$ dengan meminimumkan $\sum_{j=1}^{p}\left(x_{i j}-d_{i} a_{j 1}\right)$

e. Menghitung hasil pendugaan vektor ciri kiri yaitu $u_{1}=\frac{d}{\|d\|}$

Proses ini menghasilkan pasangan vektor ciri pertama yaitu vektor ciri kiri dan vektor ciri kanan. Setelah kriteria nilai ini konvergen, akar ciri $\lambda_{1}$ pada $\boldsymbol{L}_{1}$ dapat diperoleh dengan meminumkan :

$$
\sum_{i=1}^{n} \sum_{j=1}^{p}\left|x_{i j}-\lambda_{1} u_{i 1} a_{j 1}\right|
$$

Ini salah satu parameter regresi L1, dengan pertimbangan median.

Untuk menentukan akar ciri dan vektor ciri yang kedua dan selanjutnya, $\mathbf{X}$ yang digunakan adalah dengan mengurangi bentuk yang baru :

$$
X \leftarrow X-\lambda_{k} u_{k} a_{k}^{T}
$$

4. Menentukan $\mathbf{G}=\mathbf{U L}^{\alpha}$ dan $\mathbf{H}^{\prime}=\mathbf{L}^{\mathbf{1 - \alpha}} \mathbf{A}^{\prime} . \mathbf{G}=\left[\mathbf{g}_{1}, \mathbf{g}_{2}, \ldots . \mathbf{g}_{\mathbf{n}}\right]^{\mathbf{T}} ; \mathbf{H}=\left[\mathbf{h}_{\mathbf{1}}, \mathbf{h}_{2}, \ldots . \mathbf{h}_{\mathbf{p}}\right]^{\mathbf{T}} ; \mathbf{L}=$ $\operatorname{diag}\left(\sqrt{\lambda_{1}}, \sqrt{\lambda_{2}}, \ldots, \sqrt{\lambda_{r}}\right) ; A=\left(a_{1}, a_{2}, \ldots a_{r}\right)$;

$U=\frac{1}{\sqrt{\lambda_{1}}} X a_{1}, \frac{1}{\sqrt{\lambda_{2}}} X a_{2}, \ldots, \frac{1}{\sqrt{\lambda_{r}}} X a_{r}$

5. Membuat plot untuk obyek pertama dengan koordinat $\left(g_{11}, g_{21}\right)$ sampai obyek ke n.

6. Membuat plot untuk peubah pertama dengan koordinat $\left(h_{11}, h_{21}\right)$ sampai peubah ke $\mathrm{p}$.

\subsection{Uji Kesesuaian Biplot}

Gabriel [3] mengemukakan ukuran kesesuaian biplot (Goodness of Fit of Biplots) sebagai ukuran pendekatan adalah dalam bentuk : 


$$
\rho^{2}=\frac{\left(\lambda_{1}^{2}+\lambda_{2}^{2}\right)}{\sum_{n=1}^{r} \lambda_{n}^{2}}
$$

Dengan $\lambda_{1}$ adalah nilai eigen terbesar ke- $1, \lambda_{2}$ adalah nilai eigen terbesar ke- 2 dan $\lambda_{k}, k=1,2, \ldots$ r adalah nilai eigen ke-k. Apabila $\rho^{2}$ mendekati nilai 1 , maka biplot yang dihasilkan sangat baik. Informasi yang diberikan oleh biplot sebesar $99.93 \%$ dari keseluruhan informasi yang terkandung dalam data.

\section{Metode Penelitian}

Data yang digunakan dalam penelitian ini adalah data sekunder, yaitu data diambil dari Kopertis Wilayah VII [6] dan Pangkalan Data Perguruan Tinggi (PDDIKTI) 2016 [7]. Populasi penelitian ini adalah seluruh PTS di Jawa Timur yang berjumlah 331 PTS pada berbagai bentuk perguruan tinggi. Variabel-variabel yang diamati adalah atribut yang ada dalam laporan PDPT, yaitu: 1) Jumlah Program Studi, 2) Jumlah Dosen Tetap, 3) Jumlah Mahasiswa, 4) Akreditasi, 5) Jenjang Pendidikan, 6) Rasio Dosen terhadap Mahasiswa dan 7) Biaya Pendidikan, untuk data biaya pendidikan diperoleh dari situs web PTS yang ada di Jawa Timur []. Semua data diakses pada bulan Juli 2016.

Analisis data dilakukan secara statistik deskrptif. Analisis deskriptif dilakukan untuk mendapatkan gambaran mengenai variabel-variabel PTS di Jawa Timur. Teknik analisis data secara deskriptif dibantu dengan software Scilab dan MATLAB (Matrix Laboratory).

\section{Hasil dan Pembahasan}

Jawa Timur adalah salah satu Provinsi di Pulau Jawa yang memiliki 331 Perguruan Tinggi Swasta (PTS) dengan 1783 program studi, yaitu 83 PTS berbentuk Universitas, ada 14 PTS berbentuk Institut, 143 PTS berbentuk Sekolah Tinggi, 78 PTS berbentuk Akademi, 12 PTS berbentuk Politeknik dan ada 1 PTS berbentuk Akademi Komunitas. Sebaran PTS di Jawa Timur pada masing-masing bentuk dapat dilihat pada Tabel 1.

Tabel 1 .Objek Penelitian

\begin{tabular}{|c|c|c|c|c|c|c|c|}
\hline \multirow[b]{2}{*}{ No } & \multirow[b]{2}{*}{ Bentuk PT } & \multicolumn{2}{|c|}{ Jumlah } & \multicolumn{4}{|c|}{ Akreditasi BAN-PT } \\
\hline & & PT & Prodi & A & B & c & BIm \\
\hline 1 & Universitas & 83 & 1123 & 50 & 349 & 469 & 255 \\
\hline 2 & Institut & 14 & 113 & 2 & 42 & 47 & 22 \\
\hline 3 & Sekolah Tinggi & 143 & 422 & 6 & 75 & 243 & 98 \\
\hline 4 & Akademi & 78 & 86 & 1 & 16 & 50 & 19 \\
\hline 5 & Politeknik & 12 & 36 & 0 & 7 & 23 & 6 \\
\hline 6 & Akademi Komunitas & 1 & 3 & 0 & 0 & 0 & 3 \\
\hline \multicolumn{2}{|l|}{ Total } & 331 & 1783 & 59 & 489 & 832 & 403 \\
\hline
\end{tabular}

Sumber : Data Sekunder dari Kopertis Wilayah VII

\subsection{Analisis Biplot}

Berikut ini merupakan hasil pemetaa PTS di Jawa Timur dengan analisis biplot klasik dan robust biplot : 


\section{Pemetaan PTS bentuk Universitas}

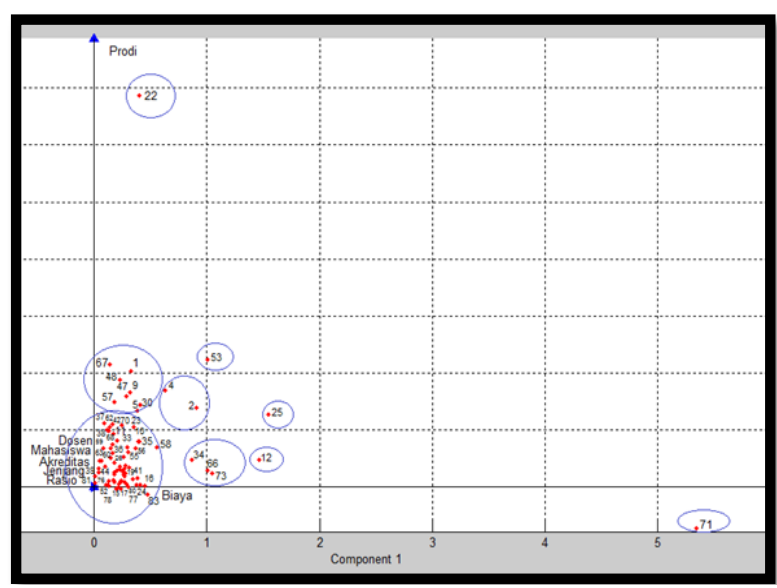

Gambar 1. Analisis Biplot Klasik PTS bentuk Universitas

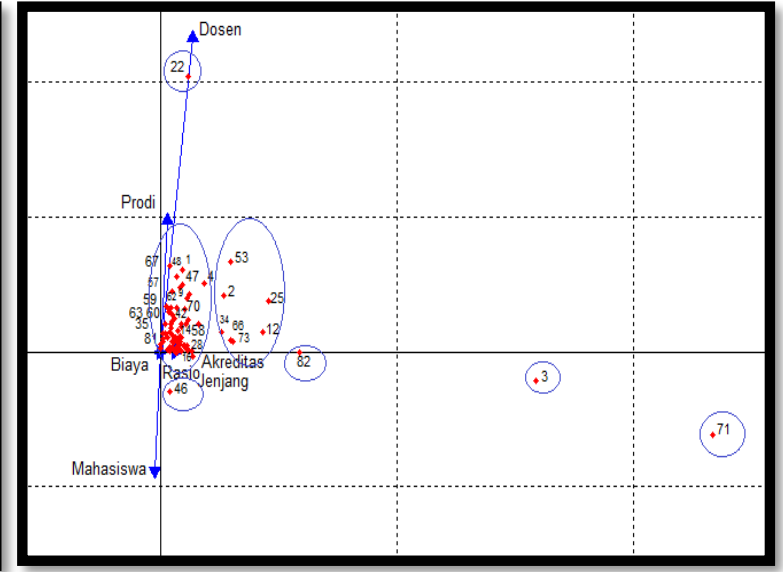

Gambar 2. Analisis Robust Biplot PTS bentuk Universitas

Penggelompokkan objek untuk PTS bentuk Universitas antara biplot klasik dan robust biplot dapat disimpulkan bahwa pada analisis biplot klasik ada 4 kelompok PTS dan 5 PTS berdiri sendiri tidak memiliki kedekatan dengan PTS lainnya. Pada robust biplot ada 2 kelompok PTS dan 4 PTS berdiri sendiri tidak memiliki kedekatan dengan PTS lainnya. Nilai keragaman variabel bentuk Universitas antara biplot klasik dan robust biplot dapat disimpulkan bahwa variabel prodi memiliki panjang vektor yang sama. Tetapi untuk variabel lainnya vektor atribut pada biplot klasik lebih besar dari robust biplot. Hal ini berarti nilai keragaman pada biplot klasik sangat besar. Pada biplot klasik terdapat 15 korelasi dan pada robust biplot hanya ada 5 korelasi. Dari analisis biplot klasik dan robust biplot terdapat lima korelasi yang sama, yaitu prodi $\left(\mathrm{X}_{1}\right)$ - dosen $\left(\mathrm{X}_{2}\right)$, prodi $\left(\mathrm{X}_{1}\right)$ - akreditas $\left(\mathrm{X}_{4}\right)$, dosen $\left(\mathrm{X}_{2}\right)$ - akreditas $\left(\mathrm{X}_{4}\right)$, akreditas $\left(\mathrm{X}_{4}\right)$ - jenjang $\left(\mathrm{X}_{5}\right)$ dan akreditas $\left(\mathrm{X}_{4}\right)$ - rasio $\left(\mathrm{X}_{6}\right)$ berkorelasi positif karena posisi vektor yang berhimpit dan searah. Untuk atribut yang tidak saling berhubungan antara biplot klasik dan robust biplot tidak memiliki kesamaan. Sedangkan pada atribut yang vektornya berlawanan pada biplot klasik tidak ada vektor yang berlawanan tetapi pada robust biplot atribut biaya dan mahasiswa arah vektornya berlawanan dengan vektor lainnya. Berdasarkan nilai variabel pada suatu objek dapat dapat dilihat analisis biplot klasik dan robust biplot sama-sama memiliki nilai diatas rata-rata dan dekat dengan rata-rata, tetapi untuk nilai dibawah rata-rata hanya ada pada robust biplot.

\section{Pemetaan PTS bentuk Institut}

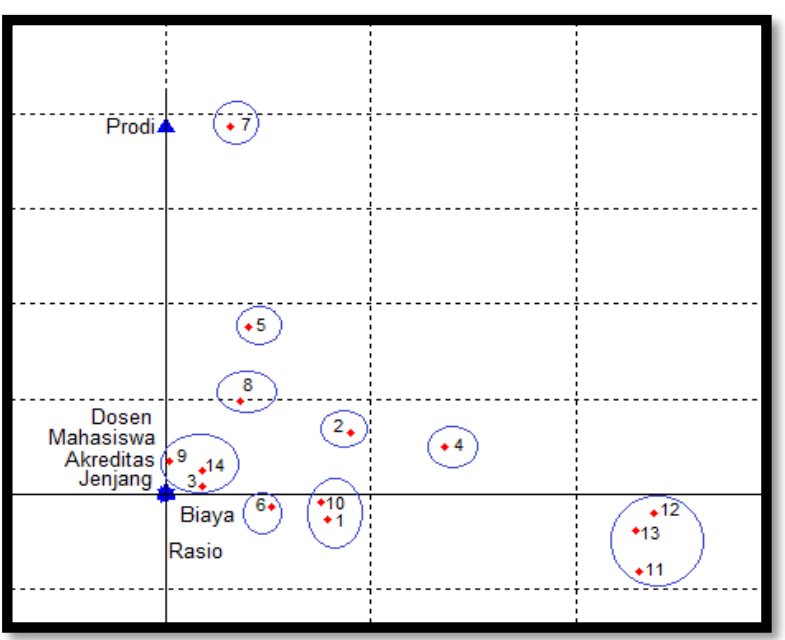

Gambar 3. Analisis Biplot Klasik PTS bentuk Institut

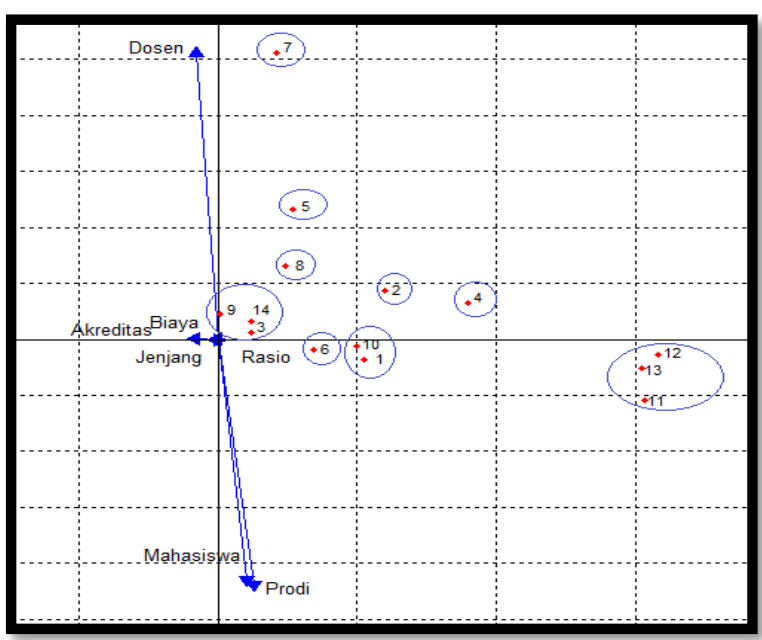

Gambar 4. Analisis Robust Biplot PTS bentuk Institut 
Untuk PTS bentuk Institut penggelompokkan objek antara biplot klasik dan robust biplot dapat disimpulkan bahwa pada analisis biplot klasik dan robust biplot sama-sama memiliki 3 kelompok PTS dan 6 PTS berdiri sendiri tidak memiliki kedekatan dengan PTS lainnya. Nilai keragaman variabel bentuk Institut antara biplot klasik dan robust biplot dapat disimpulkan bahwa variabel prodi memiliki panjang vektor yang sama. Untuk variabel dosen, mahasiswa, jenjang dan biaya pendidikan pada biplot klasik memiliki vektor yang lebih panjang dari robust biplot sedangkan untuk variabel akreditas dan rasio pada robust biplot memiliki vektor yang lebih panjang dari biplot klasik. Hal ini berarti nilai keragaman pada biplot klasik lebih besar dari robust biplot. Pada biplot klasik terdapat 11 korelasi dan pada robust biplot hanya ada 3 korelasi. Dari analisis biplot klasik dan robust biplot terdapat dua korelasi yang sama, yaitu prodi $\left(X_{1}\right)$ - mahasiswa $\left(X_{3}\right)$ dan mahasiswa $\left(X_{3}\right)$ - jenjang $\left(X_{5}\right)$ berkorelasi positif karena posisi vektor yang berhimpit dan searah. Untuk atribut yang tidak saling berhubungan antara biplot klasik dan robust biplot tidak memiliki kesamaan. Untuk atribut yang vektornya berlawanan pada biplot klasik hanya ada satu atribut yaitu rasio, sedangkan pada robust biplot ada 3 atribut yaitu akreditas, biaya dan jenjang yang arah vektornya berlawanan dengan vektor lainnya . Berdasarkan nilai variabel pada suatu objek dapat dapat dilihat analisis biplot klasik dan robust biplot sama-sama memiliki nilai diatas rata-rata, dekat dengan rata-rata dan dibawah rata-rata.

\section{Pemetaan PTS bentuk Sekolah Tinggi}

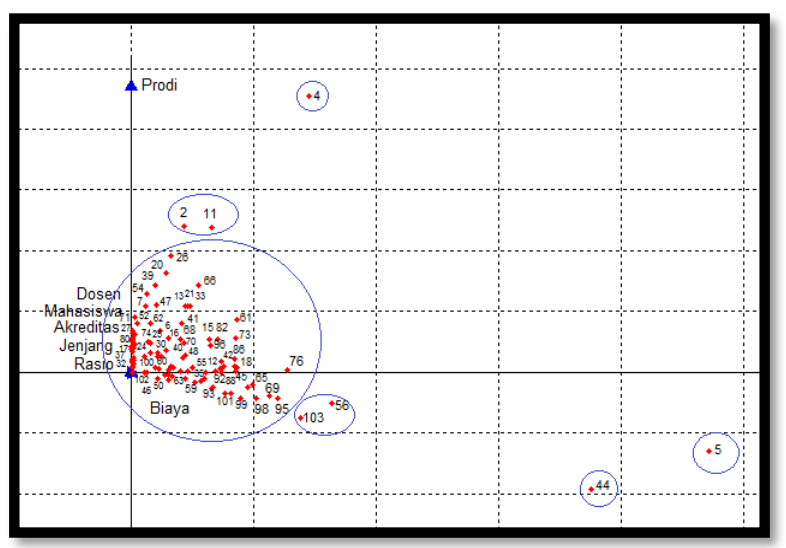

Gambar 5. Analisis Biplot Klasik PTS bentuk Sekolah Tinggi

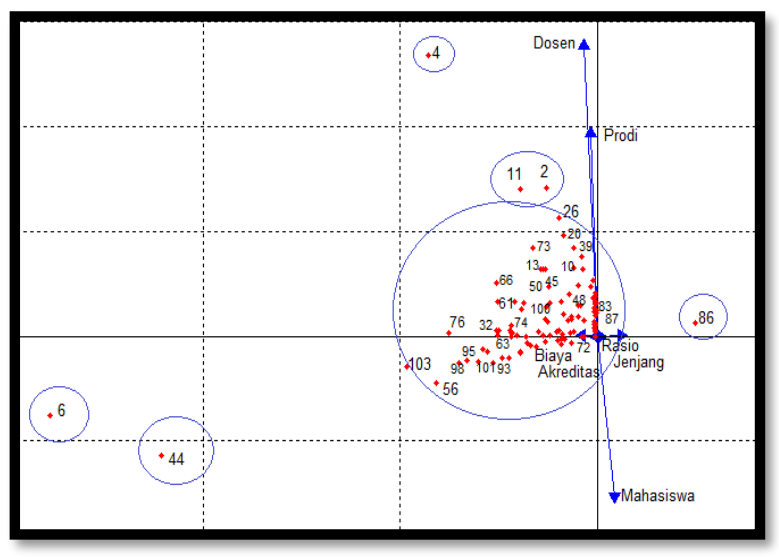

Gambar 6. Analisis Robust Biplot PTS bentuk Sekolah Tinggi

Penggelompokkan objek untuk PTS bentuk Sekolah Tinggi antara biplot klasik dan robust biplot dapat disimpulkan bahwa pada analisis biplot klasik ada 3 kelompok PTS dan 3 PTS berdiri sendiri tidak memiliki kedekatan dengan PTS lainnya. Pada robust biplot ada 2 kelompok PTS dan 3 PTS berdiri sendiri tidak memiliki kedekatan dengan PTS lainnya. Nilai keragaman variabel bentuk Sekolah Tinggi antara biplot klasik dan robust biplot dapat disimpulkan bahwa variabel prodi dan mahasiswa memiliki panjang vektor yang panjang dari robust biplot. Untuk variabel dosen, akreditasi, jenjang pendidikan dan biaya pendidikan pada robust biplot memiliki vektor yang lebih panjang dari biplot klasik. Hal ini berarti nilai keragaman pada robust biplot lebih besar dari biplot klasik. Pada biplot klasik terdapat 15 korelasi dan pada robust biplot hanya ada 3 korelasi. Dari analisis biplot klasik dan robust biplot terdapat dua korelasi yang sama, yaitu prodi $\left(\mathrm{X}_{1}\right)$ - dosen $\left(\mathrm{X}_{2}\right)$ dan jenjang $\left(\mathrm{X}_{5}\right)$ - rasio $\left(\mathrm{X}_{6}\right)$ berkorelasi positif karena posisi vektor yang berhimpit dan searah. Untuk atribut yang tidak saling berhubungan antara biplot klasik dan robust biplot tidak memiliki kesamaan. Sedangkan pada atribut yang vektornya berlawanan pada biplot klasik tidak ada vektor yang berlawanan tetapi pada robust biplot atribut rasio, jenjang dan mahasiswa arah vektornya berlawanan dengan vektor lainnya. Berdasarkan nilai variabel pada suatu objek dapat dapat 
dilihat analisis biplot klasik dan robust biplot sama-sama memiliki nilai diatas rata-rata, tetapi untuk nilai dekat dengan rata-rata dan nilai dibawah rata-rata hanya ada pada robust biplot.

\section{Pemetaan PTS bentuk Akademi}

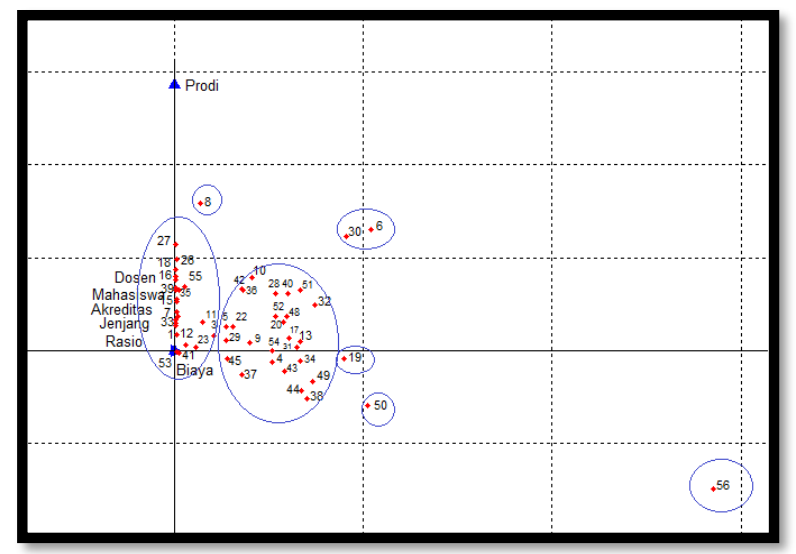

Gambar 7. Analisis Biplot Klasik PTS bentuk Akademi

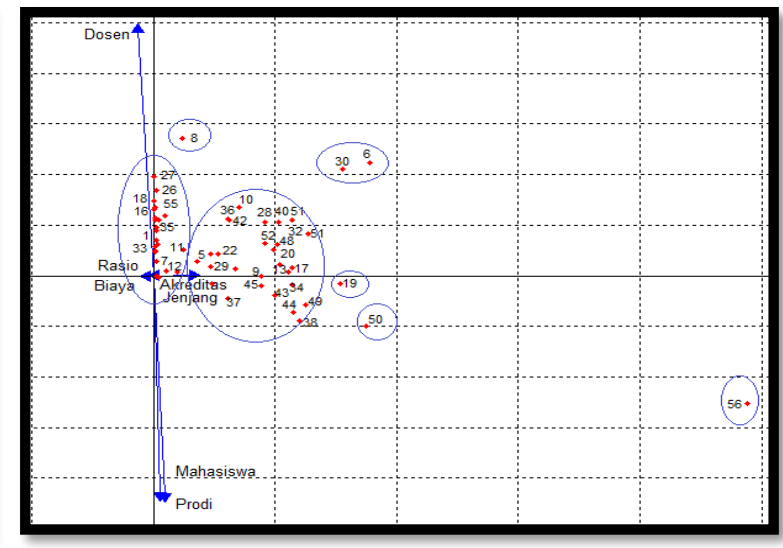

Gambar 8. Analisis Robust Biplot PTS bentuk Akademi

Penggelompokkan objek untuk PTS bentuk Akademi antara biplot klasik dan robust biplot dapat disimpulkan bahwa pada analisis biplot klasik dan robust biplot ada 3 kelompok PTS dan 4 PTS berdiri sendiri tidak memiliki kedekatan dengan PTS lainnya. Nilai keragaman variabel bentuk Akademi antara biplot klasik dan robust biplot dapat disimpulkan bahwa variabel prodi memiliki panjang vektor yang sama. Tetapi untuk variabel dosen, akreditasi, rasio dan biaya pendidikan memiliki vektor yang panjang pada biplot klasik dari pada robust biplot. Dan untuk variabel mahasiswa dan jenjang pendidikan memiliki vektor yang panjang pada robust biplot dibanding dengan biplot klasik. Hal ini berarti nilai keragaman pada biplot klasik sangat besar. Pada biplot klasik terdapat 15 korelasi dan pada robust biplot hanya ada 2 korelasi. Dari analisis biplot klasik dan robust biplot terdapat dua korelasi yang sama, yaitu prodi $\left(\mathrm{X}_{1}\right)$ - mahasiswa $\left(\mathrm{X}_{3}\right)$ dan akreditasi $\left(\mathrm{X}_{4}\right)$ - jenjang $\left(\mathrm{X}_{5}\right)$ berkorelasi positif karena posisi vektor yang berhimpit dan searah. Untuk atribut yang tidak saling berhubungan antara biplot klasik dan robust biplot tidak memiliki kesamaan. Untuk atribut yang vektornya berlawanan pada biplot klasik tidak ada vektor yang berlawanan sedangkan pada robust biplot atribut rasio arah vektornya berlawanan dengan vektor lainnya. Berdasarkan nilai variabel pada suatu objek dapat dilihat analisis biplot klasik dan robust biplot sama-sama memiliki nilai diatas rata-rata dan dekat dengan rata-rata tetapi untuk nilai dibawah rata-rata hanya ada pada robust biplot.

\section{Pemetaan PTS bentuk Politeknik}

Penggelompokkan objek untuk PTS bentuk Politeknik antara biplot klasik dan robust biplot dapat disimpulkan bahwa pada analisis biplot klasik dan robust biplot sama-sama memiliki 2 kelompok PTS dan 5 PTS berdiri sendiri tidak memiliki kedekatan dengan PTS lainnya. Nilai keragaman variabel bentuk Politeknik antara biplot klasik dan robust biplot dapat disimpulkan bahwa variabel prodi memiliki panjang vektor yang sama. Tetapi untuk variabel dosen, akreditas, jenjang pendidikan dan biaya pendidikan vektor atribut pada biplot klasik lebih panjang dari robust biplot. Dan untuk variabel mahasiswa dan rasio vektor atribut pada robust biplot lebih panjang dari biplot klasik. Hal ini berarti nilai keragaman pada biplot klasik sangat besar. Pada biplot klasik terdapat 11 korelasi dan pada robust biplot hanya ada 6 korelasi. Dari analisis biplot klasik dan robust biplot terdapat dua korelasi yang sama, yaitu dosen $\left(\mathrm{X}_{2}\right)-$ akreditas $\left(\mathrm{X}_{4}\right)$ dan dosen $\left(\mathrm{X}_{2}\right)$ - jenjang $\left(\mathrm{X}_{5}\right)$ berkorelasi positif karena posisi vektor yang berhimpit dan searah. Untuk atribut yang tidak saling berhubungan antara biplot klasik dan 
robust biplot tidak memiliki kesamaan. Untuk atribut yang vektornya berlawanan pada biplot klasik hanya ada satu atribut yaitu rasio, sedangkan pada robust biplot tidak ada vektor yang berlawanan arah. Berdasarkan nilai variabel pada suatu objek dapat dapat dilihat analisis biplot klasik dan robust biplot sama-sama memiliki nilai diatas rata-rata dan dekat dengan rata-rata.

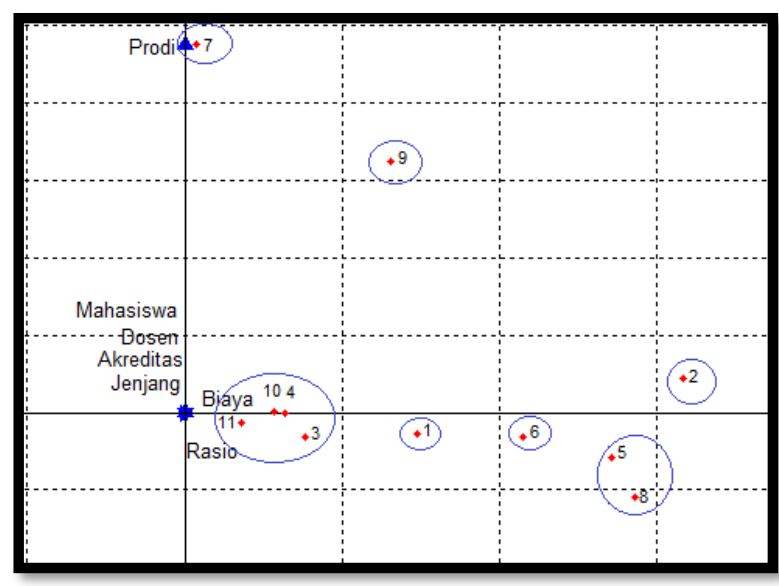

Gambar 9. Analisis Biplot Klasik PTS bentuk Politeknik

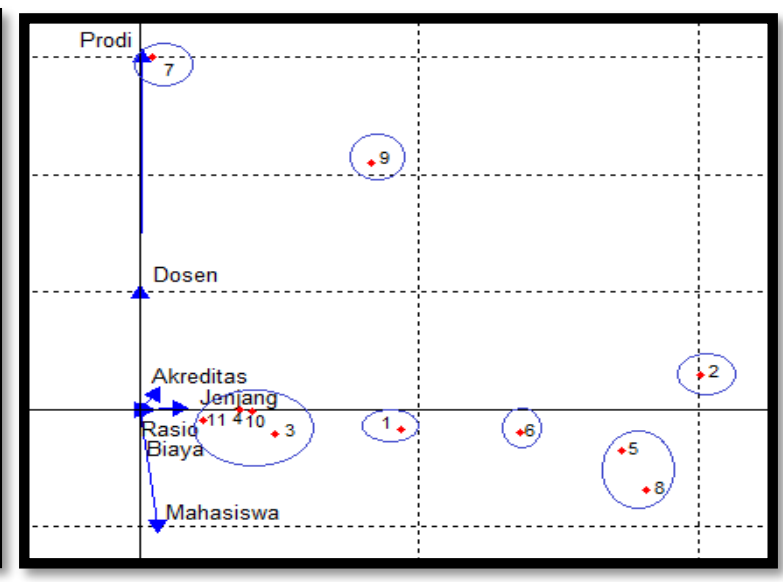

Gambar 10. Analisis Robust Biplot PTS bentuk Politeknik

\section{Pemetaan PTS bentuk Akademi Komunitas}

Karena pada Akademi Komunitas tidak dapat dilakukan perhitungan, jadi untuk akademi komunitas tidak dapat dibandingkan.

\subsection{Uji kesesuaian Biplot}

Hasil pemeriksaan kesesuaian Biplot klasik dan robust biplot dapat dilihat pada tabel 2. Nilai kesesuaian biplot klasik dan robust biplot hampir sama, keduanya memiliki nilai mendekati 1, maka biplot yang dihasilkan sangat baik. Sehingga dapat disimpulkan bahwa keduanya memiliki nilai di atas $70 \%$ dari keseluruhan informasi yang terkandung dalam data. Akan tetapi, dari hasil tersebut dapat dilihat bahwa analisis biplot klasik lebih baik dibandingkan dengan robust biplot.

Tabel 2. Nilai Kesesuaian Biplot

\begin{tabular}{|l|c|c|}
\hline \multicolumn{1}{|c|}{ Bentuk PTS } & Biplot Klasik & Robust Biplot \\
\hline Universitas & 1 & 1 \\
\hline Institut & $\mathbf{0 . 9 2 6}$ & 0.7390 \\
\hline Sekolah Tinggi & $\mathbf{1}$ & 0.9503 \\
\hline Akademi & 0.999 & 0.9985 \\
\hline Politeknik & $\mathbf{0 . 7 7 2 1}$ & 0.7262 \\
\hline Akademi Komunitas & - & - \\
\hline
\end{tabular}




\section{Kesimpulan dan Saran}

\subsection{Kesimpulan}

Berdasarkan perhitungan dari analisis biplot klasik dan robust biplot pada pemetaan PTS di Jawa Timur dapat disimpulkan bahwa hasil yang didapatkan tidak jauh berbeda walaupun cara pengerjaannya tidak sama. Penggelompokkan objek pada PTS bentuk Institut, Akademi dan Politeknik memiliki kesamaan tetapi pada PTS bentuk Universitas dan Sekolah Tinggi tidak memiliki kesamaan. Untuk keragaman dan korelasi antar variabel pada analisis biplot klasik keragamannya lebih besar dibandingkan dengan robust biplot. Untuk nilai variabel pada suatu objek sama-sama memiliki nilai diatas rata-rata, dekat dengan rata-rata dan dibawah rata-rata. Nilai kesesuaian biplot klasik dan robust biplot hampir sama, keduanya memiliki nilai mendekati 1. Namun, analisis menggunakan biplot klasik lebih baik dibandingkan dengan robust biplot.

\subsection{Saran}

Dari penelitian yang dilakukan, disarankan untuk diadakan penelitian lanjutan dengan menggunakan variabel yang bervariasi sesuai dengan segmen yang akan dikaji. Serta menentukan analisis biplot dengan metode yang lain, yang lebih mudah dan akurat, dibandingkan dengan analisis biplot klasik dengan robust biplot.

\section{Referensi}

[1] Jollife and Rawlings. (1986), Primcipal Component Analysis, Springer-Verlag, New York.

[2] Gunarto, Muji dan Syarif, Muhammad Amiruddin. 2014.Penggunaan Analisis Biplot pada Pemetaan Perguruan Tinggi Swasta di Kota Palembang, Forum Manajemen Indonesia 6 Medan.

[3] Gabriel, K.R., (1971), The Biplot Graphic Display of Matrices With Application to Principal Analysis, Biometrika, 58(3), hal.453-467.

[4] Mattjik, Ahmad Ansori dan Sumertajaya, I Made. (2011). Sidik Peubah Ganda dengan menggunakan SAS. Institut Pertanian Bogor (IPB) : Departemen Statistika.

[5] Hawkins, D.M., Liu, L., Young, S.S., (2001), Robust Singular Value Decomposition, National Institute of Statistical Science, Vol. 122, hal 1-12.

[6] Kopertis Wilayah VII. 2016. Informasi Data Perguruan Tinggi Swasta. Direktori Kopertis VII.

[7] Pangkalan Data Pendidikan Tinggi Kementrian Riset, Teknologi dan Pendidikan Tinggi. 2016. Profil Perguruan Tinggi. Kementrian Riset, Teknlogi dan Pendidikan Tinggi (http:forlap.dikti.go.id, diakses Juli 2016).

[8] Wikipedia Bahasa Indonesia. 2016. Daftar Perguruan Tinggi Swasta di Jawa Timur.http//id.m.wikipedia.org/wiki/Daftar_perguruan_tinggi_swasta_ di_Jawa_Timur. (28 April 2016). 